\title{
Encounter, Clash, and Confluence: Mohja Kahf's The Girl in the Tangerine Scarf
}

Sara Arami

\section{(2) OpenEdition \\ 1 Journals}

Electronic version

URL: http://journals.openedition.org/ces/287

DOI: $10.4000 /$ ces. 287

ISSN: 2534-6695

Publisher

SEPC (Société d'études des pays du Commonwealth)

\section{Printed version}

Date of publication: 1 April 2018

Number of pages: $43-53$

ISSN: 2270-0633

\section{Electronic reference}

Sara Arami, "Encounter, Clash, and Confluence: Mohja Kahf's The Girl in the Tangerine Scarf",

Commonwealth Essays and Studies [Online], 40.2 | 2018, Online since 05 November 2019, connection on 03 April 2021. URL: http://journals.openedition.org/ces/287 ; DOI: https://doi.org/10.4000/ces.287

\section{(c) (†) $९$}

Commonwealth Essays and Studies is licensed under a Licence Creative Commons Attribution - Pas d'Utilisation Commerciale - Pas de Modification 4.0 International. 


\section{Encounter, Clash, and Confluence: Mohja Kahf's The Girl in the Tangerine Scarf}

In her novel The Girl in the Tangerine Scarf (2006), Syrian-American Mohja Kahf engages in the representation of an experience similar to hers, the coming-of-age narrative of

a young girl in a Muslim community in the heart of Indiana. A coming of age that is strongly marked by recurring cycles of encounter, clash and confluence on various levels. By making use of such a recurring pattern, Kahf questions the view which holds identity to be fixed and ossified, and problematizes the prevalent stereotypes of gender and nationality.

Syrian-American Mohaj Kahf, a poet and novelist, was born in Damascus and moved to the United States with her parents at the age of four. In her only novel to date, The Girl in the Tangerine Scarf, she draws on her own experience of growing up in the American Midwest in order to represent the coming-of-age narrative of a young Muslim girl, Khadra Shamy, who is brought to the United States by her parents at an early age. The Girl in the Tangerine Scarf belongs to the tradition of Arab-American women's immigration fiction. Contemporary Arab-American women, who have always been spoken for either by their patriarchal home culture or the patronizing colonial host, make it their mission to contest and challenge the abounding stereotypical representations of their lives and identities in their writings. These representations, when produced by their patriarchal home culture, focus upon them as a repository of national culture or, when coming from the patronizing colonial host, fix them in the position of the passive victim of oriental patriarchy and religious practices.

In a similar manner to what Marlene Goldman argues about Canadian women's writing in her Paths of Desire, "This subversive project is by no means straightforward" (Goldman 4), since in order to achieve their goal, Arab-American women writers have no other choice but to draw upon the existing traditional discourses. Thus, as Goldman observes about Canadian women's writing, these fictions “posit a link between a subversive engagement with established discourses and attempts to disrupt the configuration of gender within society at large" (4). The difference being that Arab-American women writers such as Kahf add the question of race to the equation, to create a more complex system of subversion, and a more elaborate disruption of established discourses.

Kahf, however, takes a further step and distinguishes herself from the lot, since she finds a way to relate contemporary Arab-American women's writing to the American tradition of the novel by drawing upon another set of traditions, that is the founding myths of America, such as the myth of the prairie, and on various real and imagined geographical places, in order to treat questions of immigrant identity and to redefine Muslim-American women's subjectivity - in other words, to address both gender and national identities. In addition, she sets the story of her protagonist within the context of a Muslim community in Indiana, presenting to her readers not only one version, but various versions of Islam and the diversity that exists within the community. In this way, she fights the essentialized clichés that have haunted Muslims and been reinforced since 9/11. This article will focus on the latter aspect of her writing. 
Before moving on to the main argument, a point needs to be made. One should be aware that writing from the position of Arab-American women is by nature problematic, as by engaging with the established discourses with the aim of subverting them, authors risk being accused of "re-Orientalism." The term was coined by Lisa Lau in relation to South Asian literature in order to account for the kind of stereotyping that leads her to refer to some South Asian authors as "diasporic Orientals." For Lau, these are authors who write "as much to the West as for the East" (4), and whose self-representation "continues to be filtered through Western lenses (in a very similar style to Orientalism) and to reference the West as 'Centre' in framing the representations and anticipating the audiences" (5). Lau's analysis of re-Orientalism is part of a larger discussion in which many critics before her, such as Samir Amin, G. Arrighi, Wallerstein, and others have referred to the same concept with different terms such as ethno-orientalism, self-orientalism, internal orientalism, reverse orientalism, neo-orientalism, etc.

To avoid such pitfalls would mean not to risk writing from the position of ArabAmerican women at all and thus not to make an attempt at shifting the terms of female Muslim American identity from the passive object of patriarchal discourses to the active, self-defining subject who contests and reshapes those discourses. Kahf does take the risk to rewrite and thus rebuild the Muslim American female identity from an insider's stance. To do so, she devises both thematic and structural strategies. On a thematic level, she presents us with a coming-of-age story that is marked by recurring cycles of encounter and clash on various levels, all of which play an important role in shaping the identity of her protagonist.

The first series of encounter and conflict to be discussed are those that occur between Khadra and her homeland. In this respect, Kahf discusses the relationship between Khadra and the state of Indiana, and her relationship to the United States, both of which change drastically throughout the narrative as the protagonist is represented in a constant attempt to modify her relationship to various places in order to create a space where she feels at home. As Charles J. Stivale explains, "Home is [...] not a pre-existing space. [...] It is the continual attempt to create a space of comfort for oneself, through the arrangement of objects, practices, feelings and affects" (79).

The novel opens with adult Khadra driving back to Indiana, where she has passed most of her youth. From the very incipit Khadra's re-encounter with Indiana reveals a hostility one would not imagine existing between a person and his or her bome town: "Liar,' she says to the highway sign that claims 'The People of Indiana Welcome You" (1). The author continues with the description of what Khadra comes across on her way back to her home town, namely images that contribute to and extend this hostility:

There are silver silos and pole barns, tufts of goldthread on the meridian, and the blue day beginning to pour into the dark sky. But it is not mine, she thinks, this blue and gold Indiana morning. None of it is for me. Between the flat land and the broad sky, she feels ground down to the grain, erased. She feels as if, were she to scream in this place, some Indiana mute button would be on, and no one would hear. (2)

This passage introduces Khadra as a displaced subject, one who does not feel a sense of belonging to or ownership of the place where she has grown up. The flatness of Indiana, mentioned here for the first time, is insisted upon throughout the novel, symbolizing the inflexibility of its inhabitants, and their unwillingness to accept diversity. The history of this hostility is then represented to the readers with a flashback when 
the seemingly calm and heavenly world of childhood innocence of little Khadra playing between freshly-washed bed linens and laundry is quickly disrupted by:

a boy with heavy pink flushed cheeks on a dirt bike, tearing through the hung laundry, pulling down rope, soiling sheets with his tire tread. Khadra ran. Screamed and ran. Fell, scraped her cheekbone on the cracked asphalt. He wheeled and turned. Gunning for her. [...] "Fuck you raghead!" Brian shouted back. "We're gonna get all you fuckers!" He wheelied on "fuckers." (4-5)

As a result of these hostilities, young Khadra does not think of herself as American. In fact, Americans are represented throughout the book as the ultimate other, against whom Khadra is judged during her growing-up years. An instance of this othering could be seen when Khadra's mother gives the children chores to make sure they "didn't turn into lazy American children" (21). When Khadra's parents decide to go before a judge and take citizenship (and this only because their Syrian passports have expired, and as political activists working against the government in Syria they have no way of renewing them, and are thus paperless), the whole family goes into mourning: "To her [Khadra], taking citizenship felt like giving up, giving in. After all she'd been through at school, defending her identity against the jeering kids who vaunted America's superiority as the clincher put-down to everything she said, everything she was" (141). Thus, America is set in opposition to Khadra's whole being.

Being a displaced subject, one without a home, leads Khadra to an identity crisis. In order to overcome it, she embarks on several quests in search of the place where she belongs. The search for a place of origin is the result of a view of identity that considers it an essential entity, and which in diaspora literature is best demonstrated in the "narratives of return." Having grown up in a Muslim community, among Muslims from different countries and ethnicities, Khadra sees herself first and foremost as Muslim: "Wasn't she supposed to be an Islamic warrior woman, a Nusayba, a Samaya, an Um Salamah in exile, by the waters dark, of Babylon?" (141) So when she travels to Mecca with her family in order to do Haj, the pilgrimage every Muslim has to do during his or her life, the deterritorialized Khadra expects to finally feel in Mecca, the sense of belonging lacking in her relation to Indiana or America. Before visiting Mecca, Khadra identifies as a member of the "imagined community" (Anderson 6) of Muslims. On this account, in her first moment of encounter with Mecca, when their plane lands, she thinks to herself: "At last [...] someplace where we really belong. It's the land of the Prophet. The land of all Muslims" (159). Ironically though, throughout her stay in Mecca, Khadra comes to realize that she who believes herself to be an Arab Muslim woman, is in total conflict with this place. In Mecca Khadra is an outsider, the other, both in relation to the official religious and national discourses, and in relation to the unofficial discourse of her generation. The first clash happens when one early morning, upon hearing the call to prayer coming from the mosque right next to her mother's friend's house, she decides to go to the mosque to pray fajr:

Thirty minutes later, with a tear streaked face, Khadra was back, escorted by two burly matawwa policemen [...]. "Is this one of your womenfolk?" they asked Uncle Zaid, Saweem's husband, his face freshly washed. "We found her trying to get into the mosque." They said it as if she was a vagrant or something. (166)

It's only after this incident that her parents explain to her that women are not permitted to pray in mosques in "most Muslim countries" (168). This contradicts Khadra's dee- 
pest beliefs about the teachings of Islam: "What about the Prophet saying You must never prevent the female servants of God from attending the houses of God?"' (168). What is more disturbing to Khadra is the way the policemen have treated her for her so-called transgression: “[H]e said 'this woman' - it was like the police thought she was some kind of a bad woman, out in the street at that dark hour, alone, face uncovered. [...] And then the expression on Uncle Zaid's face when he wouldn't look at her at first and then when he recognized her: it was that look again. For a minute, she actually felt like a bad woman" (168-9).

On the one hand, here Kahf represents the workings of the discourse of patriarchy that plays upon women's sexual identities, and judges them according to the angel/ whore binary, in order to control them. She demonstrates how Khadra is thus fixed in a position of subordination and silenced, immediately treated like a "bad woman" when trespassing social conventions. On the other hand, by presenting Khadra's parents' reaction, who do not reprehend her for having broken the social codes, but instead explain them to her, she demonstrates that not every Muslim who has grown up in the so-called oriental countries accepts and approves of these social codes. This is one of the ways Kahf tries to avoid the trap of re-Orientalism. As explained before, she is writing from a difficult position, one between two cultures. Such representations of "oriental cultures" in the novel are nodal points that could be read as re-orientalizing. However, one should consider that the other option would be to grant a blanket approval, romanticizing and not criticizing the home cultures at all; a practice that would be in conflict with the purpose of Kahf's writing. The problematic position of the author is thus crystalized in such examples, where the challenges of so-called cultural representation are best illustrated.

Following Khadra's disillusionment with Mecca, another incident is narrated. It happens when their host's daughter, Afaaf, proposes to Khadra to go to her aunt's house with her where, once left alone, she makes a phone call, puts some makeup on and asks her aunt's driver to drop them off at the mall. There, another car picks them up, "full of young Saudis - two clean-shaven guys in white caftans and a girl whose black abaya was crumpled under her Gloria Vanderbilt jeans" (174), and takes them to the desert. It seems Afaaf had wanted to show off her American cousin who, to everyone's disappointment, speaks Arabic, insists on being an Arab and refuses to take her hijab off or drink alcohol. Ironically, Khadra is more "Arab" than the Arab girls. At one moment, when Afaaf disappears in another of the few cars full of young Saudis drinking and doing drugs that are accompanying them on their excursion in the desert, the young man who is left in the car with Khadra:

caught her hand by the wrist. Half playfully he wrested it down to her side. In the middle of Mecca, this was the last thing she expected.

"Let go," she said.

"Why? No one can see us," he said. Without warning, he was pulling her veil down the back of her head and pushing his other hand up against her breasts and his mouth was grazing her now exposed neck. She was squeezed up against the car door, and then he was pushing himself on top of her, his jeaned thighs taut. (177)

This incident reminds Khadra of another case of harassment, when she had been unveiled at school in the US. Only, this time, what is happening to her takes a double significance, since she is being molested, ironically, by a Saudi Muslim boy in Mecca, 
which makes it more disturbing to her. It makes her doubt if her pilgrimage would be accepted in the eyes of God. Both in the US and in Saudi Arabia, the veil acts as an operating signifier for inclusion/exclusion. Khadra is shaken and disappointed. After these experiences in Mecca, America does not seem to be the ultimate other anymore, as the binary opposition established from the beginning of the novel has now been overturned. Incidents of such sort can and do happen in both places (America and the land of the Prophet), and in some ways, Islam seems to be closer to America as Khadra's father, Wadji, had announced in one Friday sermon:

[L]et's face it: here inside America, there are many good qualities. Law and order, cleanliness, democracy, freedom to work and honestly seek the provision of the Lord $[\ldots]$, freedom to practice religion. These are Islamic qualities. America [...] is like Islam without Muslims. And our sick and corrupt Muslim home countries - they are Muslims without Islam. (144)

Thus, Khadra's attempt at feeling a sense of belonging, at finding a home in Mecca and reappropriating her identity in relation to it fails drastically. In a scene parallel to her arrival in Mecca on the plane, and for the first time from the beginning of the novel, she thinks to herself that she is going home. Indianapolis is then reterritorialized on Khadra's return, but her relationship to her supposed "home" is still far from simple as "territories are not fixed for all time, but are always being made and unmade, reterritorializing and deterritorializing" (Stival 79). Thus, the precarious ties formed after this first voyage in search of a home are unmade as a result of events that will follow.

As mentioned before, one of the principal grounds on which Khadra's identity seems to lie is religion. Throughout the book, Kahf represents various and most of the time conflicting versions of Islam confronted by Khadra in her Muslim community, and elsewhere. Other religions, like Christianity or Judaism, are represented as Islam's others, their followers referred to as "kuffar" (the unbelievers), for instance by Khadra's mother, Ebtehaj. But more importantly, different versions of Islam, such as Shiism, or what is referred to as the African American version of Islam, are also represented: "all that Elijah Mohammad business was nonsense. [...] [ $[$ t was a good thing Black Muslims like Aunt Khadija and Uncle Jamal converted to real Islam or they would be wandering astray" (24). Subsequently, one important factor that continuously reshapes Khadra's identity is her encounter and conflict with different religions and different versions of Islam. On another level, in having the narrator explore all these different versions of Islam, the author is representing something that Western readers most probably don't know much about. In this respect, the novel inevitably fulfils a didactic function.

As she is exposed to different versions of Islam, Khadra goes through various stages of religious transformation represented in the narrative by the color of her scarf and the way she wears it. Every time, she moves on from her previous religious convictions because they come into conflict with various aspects of her ever-changing identity. Such internal clashes can best be observed in Khadra's marriage to Juma, a young Kuwaiti man whom she meets at the university. The problems in their marriage start when Juma objects to Khadra's riding a bike. First, he kindly asks her not to, then he tries to cajole her by promising to make her stay worthwhile if she doesn't leave with her bike, then he mocks her, telling her she looks ridiculous on the bike with her hijab and finally he forbids her: "II forbid you,' he said, laying his hand on the bike seat. 'As your husband, I forbid you.' Khadra recoiled. She couldn't believe he would out and say that, even if 
it was Islamically valid. Her father never said things like that to her mother. It was alien to everything she felt and knew" (230). Khadra, who believes herself before all to be a Muslim woman, finds it very difficult to accept her husband's request. Two aspects of her identity clash and although she eventually gives in, "[s]omething inside her rusted a little too" (230). Incidents such as this come up in her marriage, making her admit: "I can't go on in this marriage without killing off the 'me' that I am" (242). Khadra's real problem is not with Juma, as a person, but with the demands he makes of her as an Arab Muslim woman, what is, for him, supposed to be part and parcel of who she is: "She was an Arab girl, familiar with Arab customs. He hadn't expected her to be doing things that would embarrass him. If he'd wanted to have to explain every limit of proper behavior, he'd have married an American" (227-8). Their different understandings of who an Arab Muslim woman should be clash. The ultimate conflict is caused by Khadra's pregnancy and subsequent abortion. Her husband, but also her family and all her friends are against her decision to abort her child, not because her life is in danger, but because she feels she does not want to have a baby at this moment in her life. To them, Khadra rejects her traditional and religious role as mother, "her most important work: making more Muslims" (21). Thus, her identity as a Muslim woman comes under question, and her transgressive act is viewed as a threat to the whole community, because "[b]oth in the original culture [...] and in the diaspora, the female body, especially the body of the middle-class woman, functions as the repository of cultural tradition" (Kimak 13). In a final attempt to stop her from going on with the abortion, her father tells her that his mother died giving birth to him, and so she is considered a martyr and will go straight to heaven:
"Well, I don't want to die in childbirth," Khadra said sarcastically.
"I'm not suggesting you do so," he said quietly. "I'm saying, my mother sacrificed everything for a child. Sacrificed her own self."
"Well, I am not your mother," Khadra shot back. "I don't want to be your mother."
"I didn't raise you to speak to me in that tone," he snapped, as he rarely ever did.
Yeah, you did, Khadra thought sullenly. You raised me to go out and learn, but deep down you still want me to be just like your mother. So where did you think all these contradictions would lead me if not to this frustration, this tone of voice? But I am not going to kill myself to fit into the life you have all mapped out for me. (245-6)

Khadra's abortion leads to her divorce, but more importantly, to her alienation from her family - who stop speaking to her - and her community in Indiana. Her relationship to her religion, her family, her community, and her home, the pillars of her identity, is shaken.

After her abortion and subsequent divorce, Khadra goes through a period of depression. She stays at home, sleeps, cries and does nothing, as her identity and everything she had tried to base her whole life upon fall apart. She mourns the breakdown of her self and when she is done mourning she embarks on another quest in search of another self, one that could hold up in order to be able to continue living because, as Françoise Kral points out in her Critical identities in Contemporary Anglophone Diasporic Literature, "the more identity is under threat, the more it resurfaces" (2). Khadra asks herself: "And then what? Where do you go when the first part of your life is coming to an end, and you don't know what is yet unborn inside you? Where do you go when you're in a free fall, unmoored, safety net gone, and nothing to anchor you?" (265) 
At this point in the narrative, Khadra's view on identity as an essential entity is still at work. The same logic that had led her to look for a sense of belonging in Mecca, when she identified most with the religious aspect of her self, leads her this time to go to the original homeland, "[b]ack where she came from: Syria" (266). She goes there despite the dangers that might await her, especially since her parents were political activists in their homeland. "The Baathists, the mukhabarat, the Asad, the army-police-border-patrol-visa-authorities" (266), Khadra accepts all these dangers because, for her, there is no other way to go on living than to go back to Syria: "She would risk it. Maybe she had a death wish. She was in a reckless state of mind" (267). The perspective of not making the trip and living without a sense of identity seems worse to Khadra than all the risks she may be taking by going back.

In the same way as with the trip to Mecca, a series of events happen on the voyage back to Syria that change Khadra's worldview. During her trip Khadra stays with Téta, her father's aunt who had raised him since his mother died in childbirth, a mother to Khadra's father and a grandmother to Khadra. During her stay, she listens to stories about Téta and her youth. She learns that Téta had married for love, and her husband was a Circassian, a minority group looked down upon by Syrians, and so they had to run away to get married. Téta's husband was eventually killed in Haifa in 1948 when they were running away from the Zionist militias, and because of the crowd and the circumstances she had not even been able to stop or to bury him. To Khadra's surprise, she also learns that one of Téta's best friends from her youth was Jewish. In a way, Khadra learns about her origins, realizing that Téta's generation was and is much more open to otherness than she ever imagined or was herself.

In the country of origin, she also learns her mother's secret from her aunt, one that her mother had never told her. Contrary to what Khadra believed, her mother had not been religious in her youth, did not pray or wear hijab until she went on a trip to Paris with school, where she was raped by one of her teachers. It is only after this incident that she became religious and wore her hijab very strictly. To Khadra, this is an explanation for her mother's strictness, not only in her religious views, but also in her attitude towards Khadra and her life. Therefore, once again, stories Khadra hears on her trip to Syria change her understanding of her past, altering her life narrative. This part of the novel re-establishes its connection to the tradition of the return narrative, which formed as a subgenre of travel writing. Return narratives recount the adventures embarked upon by diasporic subjects in an attempt to approach and comprehend their origins, most of the time in the hope of resolving the conflicts and contradictions they encounter in their sense of self. Nevertheless, it is essential to note that in comparison to travel writing and its effects on national identity and the nation, "return narratives [eventually] formulate identities beyond singular national affiliations; they write the diaspora and establish a transnational, diaspora consciousness" (Kindinger 85).

To this end, and ensuing the adventures of the trip to Syria, Kahf also introduces the readers to the figure of the poet, whom Khadra meets at the top of Mount Qaysoon. It is impossible to determine whether the poet, who serves to help Khadra in overcoming the either/or, right/wrong, black or white logic she has been brought up with, is a real character or a figure of Khadra's imagination. In this sense, he is a liminal figure, standing between reality and imagination. His liminal position is essential to his role in the novel, helping Khadra question her dearest beliefs: 
"Why do you spend so much time worrying about what God thinks of you?" [...] [H]is low voice seemed to come right out of her own gut. She didn't think she'd shared that much of her state of confusion. "It's the other way around, you know. God is what you think of God, you know." (301)

Khadra, Téta, Téta's friend and the poet visit a synagogue together, where Khadra meets the rabbi, in an incident that makes her break down once again. She realizes how arbitrary all the lines were that she had drawn between people and religions, right and wrong, and these are the lines that caused all the conflicts and contradictions in her life:

[The Rabbi] spoke with the deepest Damascene accent Khadra had ever heard, drawling out the last " $\mathrm{m}$ " on every word. [...] His voice in those chords was like family to her. Something vibrated in her chest. [...] It's just that, all this time, she'd thought of them as Them, these people over There, not all the same of course, she knew that, but, still not part of Us. Never. [...] [S] he could suddenly imagine being his granddaughter. Blood and soil and home, boiling coffee in the kitchen, puttering about in faded house slippers to find him dozing in his chair, his finger on a word in the holy book in his lap. And then this whole other life opened up in her mind. It sent her whirling in mad agony. This incidental skin, this name she wore like a badge-glance down, check it - what was it again? Had it changed? Was it always changing? Who was she? What was she, what cells of matter, sewn up into this Khadra shape, this instar? Imagine!

It was suddenly too much. She began to gasp. Great gasping sobs poured out and wouldn't stop. (305-6)

Khadra then is taken back to Teta's house, where she goes through a painful transformation. She sleeps and wakes and cries and dreams and blesses everyone and everything. She thinks of all the people she had once held at bay, people she had judged and turned away: "Now the barrier was removed, and they all rushed into her heart" (306-7). She feels connected to all of them. In a state somewhere between dream and reality, a liminal state, Khadra opens up to otherness, and so all the conflicts resolve themselves and confluence takes their place. When she starts praying after this incident, she feels as if she is praying for the first time: "All that had been lost was returning. All that had been disconnected was connected again" (307).

Throughout the novel, Kahf makes use of an extended metaphor to reflect on Khadra's transformations, that of the instar, which is "what entomologists call the body of the bug in its different stages of life" (250) - "a phase between two periods of molting in the development of an insect larva or other invertebrate animal" (OED). This in-betweenness reflects Khadra's diasporic identity and extends the trope of liminality used in diverse manners in the novel. As Khadra explains to her friend Joy, the adult instar, the mature bug, is called "imagine." It is after this incident that Khadra emerges from her metaphoric molting metamorphosed into an "imagine," as her new self is formed around the idea of acceptance, and an ability to imagine herself as one with her others.

It is on this trip to Syria that Khadra buys the tangerine silk out of which she makes two identical scarves for herself and for Téta. Thus, her tangerine scarf, that of the novel's title, takes a symbolic significance connecting her to this trip, the development of her self, her mother and her country of origin. On the first day after her difficult transformation Khadra lets her slipping scarf drop off to her shoulders on a picnic with Téta and the poet. "She saw Téta looking at her. Téta got it [...], maybe she knew about kashf, the unveiling of light. How veiling and unveiling are part of the same process, the same cycle, how both are necessary; how both light and dark are connected moments 
in the development of the soul in its darkroom" (309). In this way, Kahf overturns the binary opposition between veiled and unveiled. During the days after the unveiling, Khadra's body has to relearn how to go about unveiled. Thus, she also goes through a physical phase of transformation (like an instar) as, at the beginning, her body feels off-balance. When upon her return to the United States, Khadra decides to put the tangerine scarf on, she wears it differently than she did before. "Not tightly, the way Ebtehaj wore it. Loosely, so it moved and slipped about her face and touched her cheek, like the hand of a lover" (313). The looseness of her hijab symbolizes the philosophy of acceptance she has come to learn with her heart, the consequence of the overturning of the binary. The hijab itself stands for her heritage and she wants to show it off as she now feels at peace with her own hybrid personal history and celebrates it.

On her return from Syria, Khadra is certain that if there is a home for her, it is America. She embraces her Americanness and reconfigures her own concept of home, a territorial assemblage, which precisely because of being an assemblage survives and contains contradictions. However, Khadra does not want to go back to Indiana, because she does not see a place for her new self, a self open to the whole world, in her Muslim community " $[\mathrm{w}]$ here everyone who knows you knows exactly what you are supposed to become. [...] And then Indiana itself, the flat land that felt like a trap" (315). She then decides to move to Philadelphia, where ironically, she feels like a Hoosier. It takes a last voyage back to Indiana seven years later, when Khadra gets to mourn the death of Zuhura, a young African American Muslim girl who had been murdered by the $\mathrm{Ku}$ Klux Klan years before, for Khadra to be able to resolve her conflicts with her homestate Indiana. To Khadra, Zuhura becomes the symbol of the contradictory hopes that their Muslim community had for their young girls and at the same time "the infuriating, confining assumptions the Americans put on" them, when all she had been was just a regular Muslim "girl looking for a way to be, just be" (358). In a way, the whole novel - by engaging with the terms of the debate, and by representing the seemingly unresolvable contradictions of not only writing from, but being in the position of the Arab-American woman - could be seen as an attempt to open a space in American society where these women could "just be." The author thus draws upon the terms of the discourse, engages with them and shifts them so that they could contain such identities. It is only after mourning the death of Zuhura that Khadra comes to the realization:

She looks around at the white people, too - the Americans - no wait, she's American now - the other Americans. [...] Midwesterners - Hoosiers - set in their ways, hardworking, steady, valuing God and family. Suspicious of change. In a funny way, Khadra realizes suddenly, as she surveys the crowd: they're us, and we're them. Hah! My folks are the perfect Hoosiers! (438)

The novel follows a circular pattern as Kahf ends it where she had started: with Khadra in Indiana, only she is not the same. Throughout the novel, she goes through various stages of change and transformation, some minimal, some drastic. Her identity shatters and is reformed several times to a point that at the end of the novel the readers are sure she will still go on to transform. She is Kristeva's "subject in process" (22), a subject continually reforming himself/herself, never wholly representable and never complete. By the end of the novel, Khadra has stopped searching for "the place" where she belongs, and has understood with her heart, has come to the state of "yaqin," that she has to surrender and accept the different and sometimes conflicting aspects not only of 
her identity, but also those of others. In her novel, Kahf thus questions the view which holds identity to be fixed and ossified, and problematizes the prevalent stereotypes of gender, nationality, and religion. She portrays the self as threshold, a zone in between two multiplicities, but also a zone of proximity where the elements of multiplicities come into contact, and pass through and between each other (Deleuze and Guattari 249).

Furthermore, the author reflects this view on a structural level. The sixty-six chapters of the novel are neither numbered, nor do they have a title, but each and every one of them begins with an epigraph which relates in some way to the content of that chapter. Kahf has chosen the epigraphs from extremely diverse sources: from religious sources such as the Quran, the Bible or the Prophet's sayings, to scientific ones such as Sue Hubbell's Broadsides from the Other Orders: A Book of Bugs, to books on history and philosophy such as James H. Madison's The Indiana Way and Søren Kierkegaard's Fear and Trembling, to mythological books like Diane Wolkstein and Samuel Kramer's Inanna, Queen of Heaven and Earth, to English and American, Russian, Egyptian, Iraqi, Persian, etc. literature, poetry and prose, to song lyrics, to books on Sufism or by famous figures of Sufism such as Rumi or Attar. This polyphonic intertextuality is the manner in which she enacts her view on identity as hybrid, made up of various multiplicities coming into contact with and passing through one another. ${ }^{1}$ In this way, not only does she incorporate hybridity into the soul of her novel, but she also knits a web that connects all of these texts together and puts them on the same level, subverting hierarchies and undermining the superiority, verisimilitude or claim to truth of scientific, historical or even religious texts. Her use of intertextuality problematizes the nature of fact and by "problematizing the nature of 'fact,' [it] strategically call[s] into question the supposedly historical and factual discourses that have defined what it means to be female" (Goldman 7), but also what it means to be Muslim American. She reinforces her authority to rewrite herself back into history, and to make new maps of gender and national identities. Her novel demonstrates the possible difficulties of coming to terms with hybridity in the world we are living in, but could also be regarded as a celebration of hybridity, itself an attempt at confluence.

Sara ARAMI

University of Strasbourg / SEARCH 2325

\section{Works Cited}

Anderson, Benedict. Imagined Communities. 1983. London: Verso, 2006.

Cuddon, J.A., et al. A Dictionary of Literary Terms and Literary Theory. Oxford: Wiley-Blackwell, 2013.

Deleuze, Gilles, and Félix Guattari. A Thousand Plateaus: Capitalism and Schizophrenia. Trans. Brian Massumi. Minneapolis: UP of Minnesota, 1987.

1. For Mikhail Bakhtin hybridity is when "one single speaker could speak with a hybrid voice containing more than one language, culture or belief system" (Ryan 636). In other words, "hybridity [...] resides in [...] heteroglossia, or polyphony; similarly, he contends, polyphonic narratives have the potential to call into question authoritative discourse" (Cuddon 334), which makes the use of a polyphonic narrative very apt in the case of Kahf's novel. In addition, for Homi Bhabha, "cultural identities are constantly shifting, incorporating a multiplicity of influences" (Ryan 636). That is what leads me to interpret Kahf's polyphonic use of intertextuality as her way of enacting hybridity on a structural level. 
Goldman, Marlene. Paths of Desire: Images of Exploration and Mapping in Canadian Women's Writing. Toronto: UP of Toronto, 1997.

KAHF, Mohja. The Girl in the Tangerine Scarf. New York: Carroll \& Graf, 2006.

KIMAK, Izabella. Bicultural Bodies: A Study of South Asian American Women's Literature. Bern: Peter Lang, 2013.

Kindinger, Evangelia. Homebound: Diaspora Spaces and Selves in Greek. American Return Narratives. Dissertation. Heidelberg: Universitätsverlag, 2015.

Král, Françoise. Critical Identities in Contemporary Anglophone Diasporic Literature. Basingstoke: Palgrave Macmillan, 2009.

Kristeva, Julia. Revolution in Poetic Language. Trans. Margaret Waller. New York: Columbia UP, 1984. Trans. of La Révolution du langage poétique. Paris: Seuil, 1974.

LAU, Lisa. Re-orientalism and Indian Writing in English. New York: Palgrave Macmillan, 2014.

Ryan, Michael, et al. The Encyclopedia of Literary and Cultural Theory. Malden: Wiley-Blackwell, 2011.

Stivale, Charles J., ed. Gilles Deleure, Key Concepts. Chesham: Acumen, 2005.

The Oxford English Dictionary, Oxford UP, n.d. Web < http://www.oxforddictionaries.com/definition/ english/instar>. Consulted 31 August 2016. 